reaction which has been utilized for the release of atomic energy. It consists of thirty units, each representing the nucleus of an atom of uranium 235 or plutonium. A unit consists of two portions held together by a catch which, when released, allows the two portions to fly apart, while at the same time projecting upwards three table-tennis balls representing neutrons. A single 'neutron' dropped on the catch of one of the units disintegrates this unit, and the three ejected 'neutrons' impinging on neighbouring units cause them to disintegrate, thus initiating the chain reaction. Both these models have been demonstrated at the Physical Society's science meetings, at the Society's Exhibition of Scientific Instruments and Apparatus, and also at the recent Royal Society conversazione, where they have aroused considerable interest.

\section{Beit Memorial Fellowships for Medical Research}

The Trustees of the Beit Memorial Fellowships for Medical Research have received with regret the resignations of Lord Rayleigh and Lord Macmillan of Aberfeldy; Sir Henry Dale and Lord du Parcq have been appointed to succeed them. The following elections have been made: Fourth Year Fellowship ( $£ 700$ a year): F. Sanger, to study the structure of proteins with special reference to insulin (at the Department of Biochemistry, University of Cambridge). Junior Fellowships (normal value $£ 600$ a year): J. W. Lyttleton, to study the purification and subsequent physico-chemical characterization of proteins involved in the coagulation of blood (at the Lister Institute of Preventive Medicine, London); A. J. Marshall, to study the humoral and nervous control of the decidual reaction of the mammalian uterus (at the Department of Zoology and Comparative Anatomy, Oxford); L. Silberman, to study the community costs of tuberculosis in terms of public assistance and industrial outlay to patients and dependants, man-day wastage and social service provisions with special reference to the problem of reinstatement and revocation (at the University of Birmingham); Dr. G. Weber, to investigate the reactions and behaviour of physiologically important proteins (at the Sir William Dunn School of Biochemistry, University of Cambridge).

\section{Institution of Electrical Engineers: Awards}

The Council of the Institution of Electrical Engineers has made the following awards of premiums for papers read or accepted for publication during the session 1946-47. Group A : Institution Premium : Dr. H. G. Booker; Kelvin Premium : Dr. H. A. H. Boot and Prof. J. T. Randall; John Hopkinson Premium: H. A. Thomas. Group B: Non-Section Premiums : J. R. Mortlock and C. M. Dobson (Ayrton Premium), J. Hacking and J. D. Peattie (Llewellyn B. Atkinson Premium), C. H. Sparks (Extra Premium); Installations Section Premium: V.J. Francis and W. R. Stevens (Crompton Premium), F. Widnall and R. Newbound (Swan Premium), C. F. Freeman and H. V. Mather (Extra Premium); Measurements Section Premiums : W. Casson and Dr. F. H. Last (Silvanus Thompson Premium), Dr. F. M. Bruce (Mather Premium), Dr. A. L. Whiteley (Extra Premium), G. H. Farrington (Extra Premium), Dr. A. M. H. Arnold (Extra Premium); Radio Section Premiums : Dr. D. C. Espley, E. C. Cherry and M. M. Levy (Duddell Premium), C. Crampton (Extra Premium), W. Ross (Ambrose Fleming Premium), Dr. D. Gabor (Extra Premium), J. Bell,
M. R. Gavin, Dr. E. G. James and G. W. Warren (Extra Premium), C. J. Banwell (Extra Premium), Dr. J. H. Fremlin, A. W. Gent, D. P. R. Petrie, P. T. Wallis and Dr. S. G. Tomlin (Extra Premium), D. Cooke, Z. Jelonek, A. J. Oxford and E. Fitch (Extra Premium) ; Transmission Section Premiums : G. T. Garwood (Sebastian de Ferranti Premium), T. R. P. Harrison (John Snell Premium), R. C. Cuffe (Extra Premium). Group C: Fahie Premium : E. P. G. Wright; Paris'Exhibition (1881) Premium : W. Fordham Cooper; Webber Premium: W. E. C. Lampert; Overseas Premium (for senior members) : T. S. Skillman.

\section{Announcements}

The First Class of the Order of Agriculture has been conferred on Dr. W. Lawrence Balls, recently chief cotton technologist of the Egyptian Ministry of Agriculture, by the King of Egypt on the occasion of his resignation from that country's service.

Prof. Arthur Holmes, regius professor of geology in the University of Edinburgh, has been elected a member of the Section of Natural Sciences of the Royal Netherlands Academy of Sciences.

Prof. Gustave Ribaud, professor of pyrometry in the University of Paris, has been elected a member of the Section of General Physics of the Paris Academy of Sciences.

IN connexion with the recent International Physiological Congress, the University of Oxford conferred the honorary degree of D.Sc. on the following : Prof. S. A. S. Krogh, emeritus professor of zoophysiology in the University of Copenhagen; Prof. A. SzentGyörgyi, professor of biochemistry in the University of Szeged; Dr. H. S. Gasser, director of the Rockefeller Institute for Medical Research; Prof. B. A. Houssay, recently professor of physiology in the University of Buenos Aires; and Dr. C. H. Best, professor and head of the Department of Physiology, University of Toronto.

Profs. A. C. Chibnall, G. R. Cameron and D. Brunt have been appointed members of the Agricultural Research Council. Sir Frank Engledow and Prof. James Gray retired from membership of the Council on July 1 on the expiry of their terms of office.

DR. C. L. F. Hunter has been appointed by Pal Chemicals, Ltd., as director of the Bray Research Station, which is carrying out research into agricultural problems.

Dr. Frans Verdoorn, managing editor of Chronica Botanica, has been appointed an honorary staff member of the Government Botanic Gardens, Buitenzorg, Java, on the occasion of the hundred and thirtieth anniversary of the Garden on May 18, in recognition of his work, during the war years, on behalf of the scientific institutions of the Netherlands Indies.

THE following appointments in the Colonial Service have been announced: R. B. Blyth, to be superintendent of agriculture, Nigeria; J. L. Congdon, to be agricultural officer, Aden; H. W. Dougall, to be agricultural chemist, Sierra Leone/Gambia ; J. M. Waterston (plant pathologist, Bermuda), to be senior botanist, Nigeria ; L. R. Langridge (senior surveyor, Nigeria), to be divisional surveyor, Nigeria; E. D. Stanfeld (director of surveys, Jamaica), to be superintendent, Crown Lands and Surveys, Hong Kong. 